\title{
Przyroda jako wartość w edukacji dla zrównoważonego rozwoju
}

\author{
Helena Ciążela, \\ Ligia Tuszyńska \\ Akademia Pedagogiki Specjalnej im. Marii Grzegorzewskiej w Warszawie \\ ul. Szczęśliwicka 40, 02-353 Warszawa, hciazela@aps.edu.pl
}

\section{Streszczenie}

Wartości związane z rozwojem zrównoważonym (sustainable development) stanowią istotną kwestię, ponieważ są zakorzenione w zagrożeniach dotyczących człowieka, w najbardziej elementarnych kwestiach. Niezrównoważenie rozwoju współczesnej cywilizacji niesie za sobą zagrożenie dla całej ludzkości. Troska o środowisko nie uwzględniająca aspiracji i dążeń społecznych może stać się źródłem konfliktów i napięć mogących destabilizować sytuację polityczną. Artykuł zwraca uwagę na relacje człowieka z przyrodą od najmłodszych lat. Głównym problemem jest kształtowanie świadomości ekologicznej przez postrzeganie przyrody jako podstawowej wartości dla człowieka. Kształtowanie wartości w odniesieniu do otaczającej przyrody i najbliższego środowisku dziecka może przyczynić się do zrównoważonego rozwoju. Z przeglądu badań wynika, że przyroda w świadomości internautów nie jest utożsamiana z wartością dla człowieka.

\section{Slowa kluczowe}

edukacja, przyroda, wartości, zrównoważony rozwój

\section{Wstęp}

Gdy mówimy o wartościach związanych z rozwojem zrównoważonym (sustainable development) kwestią najistotniejszą jest to, że są one zakorzenione w zagrożeniach dotyczących nas wszystkich w najbardziej elementarnych kwestiach. Niezrównoważenie rozwoju współczesnej cywilizacji niesie bowiem zagrożenie dla całej ludzkości. Nadmierna eksploatacja środowiska naturalnego w imię celów ekonomicznych może przekreślić perspektywy godnej egzystencji przyszłych pokoleń, a nawet samą możliwość tej egzystencji. Troska o środowisko nie uwzględniająca aspiracji i dążeń społecznych może stać się źródłem konfliktów i napięć mogących zdestabilizować sytuację polityczną. Wszystko to w dzisiejszym zglobalizowanym świecie ma również globalny charakter. Rozwój cywilizacyjny nie idzie w parze z rozwojem kulturowym.

Przez tysiąclecia ludzkość żyła w wielu izolowanych skupiskach, które często mogły, a przede wszystkim nie musiały, o sobie na wzajem wiedzieć i pozostawać pozostawały pogrążone we własnych problemach. Jednak współczesny rozwój techniczny, gospodarczy i społeczny uczynił rzeczą coraz bardziej oczywistą przekraczanie lokalnych granic i faktyczne zjednoczenie ludzkości w jedną cywilizację globalną. Uczynił ludzkość wspólnotą losu, dla której globalne zagrożenia stają 
się wyzwaniami egzystencjalnymi. Gdy mówimy o zagrożeniach globalnych, mówimy o procesach, które mogą zagrozić naszej wspólnej przyszłości, albo nawet ją przekreślić.

\section{Aksjologia i edukacja zrównoważonego rozwoju}

Nauka zajmująca się wartościami nazywa się aksjologią, od greckich słów axios -(warte, cenne, godne), i logos - (nauka, wiedza,) (Tatarkiewicz 1990). Aksjologia jest nauką oceniającą rzeczy pod kątem ich wartości, znaczenia, użytkowości. Z tych też powodów stanowi ona nie tylko integralną część realistycznej filozofii, lecz wspólną podstawę dla nauk humanistycznych. Dlatego nie może być obojętna dla psychologii, pedagogiki czy socjologii, które próbując zrozumieć świat i człowieka, nie mogą ignorować fundamentalnych wartości ludzkiej osoby (Kowalczyk 1986: 37).

Aksjologia to w sensie najogólniejszym nauka o wartościach i wartościowaniu. W praktyce naukowej i dydaktycznej jako aksjologię określamy również uogólnienie dotyczące wartości jakiegoś obszaru badań czy aktywności edukacyjnej. W tym sensie możemy mówić o aksjologii rozwoju zrównoważonego i zastanawiać się nad miejscem w niej poszczególnych wartości. Glob ziemski okazuje się depozytem, który otrzymaliśmy w użytkowanie z rąk przodków i który powinniśmy oddać swoim następcom w stanie pozwalającym im żyć nie gorzej niż my (Birnbacher 1999). W miarę narastania tempa postępu technologicznego świadomość tego faktu zaczęła w coraz większym stopniu przykuwać uwagę najwybitniejszych intelektualistów współczesności (Ciążela 2006). Doświadczeniem granicznym stała się druga wojna światowa uświadamiająca możliwość globalnych i nieodwracalnych zmian ludzkiego świata. Najbardziej symbolicznie ujął ten problem Georg Picht określając swoje filozofowanie jako "filozofowanie po Auschwitz i Hiroszimie" ${ }^{1}$. To nowe filo-

1 Podobnie definiuje ten punkt przełomu Hans Jonas w swoim, znanym eseju Idea Boga po Auschwitz (Jonas, 2003) uznając doświadczenie drugiej wojny światowej za kluczowe dla naszej współ- zofowanie od samego początku wychodziło z założenia, że nowym okolicznościom ludzkiego życia potrzebna jest rewolucja w myśleniu i wychowaniu.

W swojej doniosłej pracy Zasada odpowiedzialności. Etyka dla cywilizacji technologicznej Hans Jonas postuluje zmianę dotychczasowej etyki: „...wraz z osiagnięciem pewnego stadium rozwoju naszych możliwości zmienita się natura ludzkiego dziatania; ponieważ zaś etyka zajmuje się działaniem, powinien wynikać stad wniosek, $\dot{z}$ z zmieniona natura ludzkiego działania wymaga również zmiany etyki. Nie chodzi tu jednak tylko o to, że do zajmujacych etyke przypadków doszły nowe obiekty działania, do których trzeba zastosować ogólnie przyjęte zasady postępowania, ale że zmiana owa posiada sens bardziej radykalny: jakościowo nowa natura pewnych naszych dziatań otwarta nowy wymiar etycznej ważności, dla której wśród wzorców i kanonów etyki tradycyjnej nie ma precedensu"(Jonas 1996: 21-22.)

Nie mniej istotny, na tej drodze refleksji, okazuje sformułowany w 1947 roku przez Bogdana Suchodolskiego w pracy Wychowanie dla przyszłości postulat nowej perspektywy wychowawczej: „Ta nowa sytuacja, stanowiaca specyficzna wtaściwość doby dzisiejszej, jest sytuacja wymagajaca od ludzi nowej postawy, z gruntu innej niz ta, która przywykli zajmować od wieków. Postawy zwiąanej z umiejętnościa myślenia kategoriami światowymi, nie lokalnymi. I jak w stosunku do nowej sytuacji produkcyjno-technicznej, potrzebna jest nowa postawa ludzka i potrzeba przezwyciężenia nałogów dawnych, pozbawionych sensu $w$ zmienionych warunkach, podobnie $i$ w tym zakresie rozszerzajacych się kontaktów i zależności spoteczno-ekonomicznych niezbędna jest postawa nowa, dźwigajaca sie ponad nawyki dawnej... . Jak poczucie przynależności do narodu było czymś zasadniczo innym niz poczucie przynależności do rodu tak i poczucie przynależności do ludzkiej rodziny

czesności jako moment, w którym samo istnienie Boga jako kogoś potwierdzającego się w człowieku stało się przedmiotem ludzkiej odpowiedzialności. 
wspótzamieszkującej ziemię będzie czymś zupetnie nowym. Uczucia tej przynależności $i$ wymagany przez nie normatywizm musza być ksztattowane od podstaw" (Suchodolski 1947: 25-26).

Dla tych ogólnych formuł postulatów rozwój cywilizacji wymusił konkretyzację i uszczegółowienie. Najważniejsze okazały się dokonania przełomu lat 60-tych i 70tych. Opracowany i przedstawiony na forum ONZ tzw. Raport U Thanta po raz pierwszy ujął świat człowieka z perspektywy globalnej (Człowiek..., 1971). Opracowany na zlecenie Klubu Rzymskiego Raport Granice wzrostu przedstawił pierwszą próbę symulacji komputerowej ukazującej trendy rozwoju ludzkości w zależności od przyjętej strategii wzrostu gospodarczego (Meadows i in. 1973). Natomiast zagadnienia edukacji w nowych globalnych realiach Klub Rzymski sprecyzował w raporcie Uczyć się bez granic. Jak zewrzeć „luke ludzką?”, gdzie sformułowany został aktualny do dzisiaj program edukacji antycypacyjnej i wspólnotowej (Botkin i in. 1973).

Ukoronowaniem dyskusji wywołanej przez wspomniane wyżej wystąpienia i dokumenty stał się Raport opracowany przez komisję pod kierownictwem Gro Harlem Brundtland Nasza wspólna przyszłość (Brundtlant 1991), opublikowany w 1987 roku (Ciążela op cit.). Najważniejszym elementem raportu stał się postulat „rozwoju trwałego i zrównoważonego" (sustainable development), określanego najczęściej w Polsce jako „zrównoważony rozwój” (ZR). Sformułowany w Raporcie Brundtland postulat zrównoważonego rozwoju ukierunkował dalszą dyskusję i badania oraz teorię i praktykę edukacyjną. W ich kontekście zrównoważony rozwój zdefiniowany został jako: „teraźniejszy i przyszły dobrostan ludzkości, w powiązaniu z postawą szacunku dla integralności i ochrony utworów przyrody, od trwania i rozwoju których ściśle zależne sq trwanie i rozwój antroposfery, w imię nienaruszania równowagi ekologicznej. (Domeracki 2010: 12 ).

Jak podsumowuje znaczenie koncepcji zrównoważonego rozwoju polski filozof i ekoetyk Włodzimierz Tyburski: „jest wtaściwie jedyną realna propozycja globalnej filozofii rozwoju, która w obliczu negatywnych doświadczeń ostatniego stulecia zmierza do rewizji tych sposobów myślenia i programów, które wyznaczaty dotychczasowy kierunek rozwoju cywilizacji. Chodzi o możliwości przezwyciężenia zagrożeń dobrostanu człowieka i powstrzymania procesów, które godzq w egzystencjalne podstawy bytu ludzkości" (Tyburski 2007).

Jak podaje Zbigniew Hull, na przekonania filozoficzne naukowców i budowanie teorii zrównoważonego rozwoju składają się rozmaite aksjologiczne, ontologiczne, czy antropologiczne, poglądy i budowane na nich wartości (Hull 2005). Określają one w różnorodny sposób podejście do relacji: człowiek - środowisko przyrodnicze, jednostka - społeczeństwo, relacje międzypokoleniowe, jak również różnice między rozwojem a wzrostem ekonomicznym.

\section{Przyroda jako wartość w aksjologii rozwoju zrównoważonego}

Gdy analizujemy postulat zrównoważonego rozwoju z perspektywy aksjologicznej, za kluczową uznać musimy wartość przyrody - „środowiska naturalnego”, jako punktu wyjścia dla definiowania charakteru budowanego przez człowieka „świata sztucznego", w którym może on realizować swoje potrzeby (Picht 1981a). Centralną relacją okazuje się tutaj przyroda rozumiana jako całość, wobec której człowiek musi się samookreślić. Odrzucenia, z perspektywy rozwoju trwałego i zrównoważonego, wymagają te wszystkie postawy, które przyrodę traktowały jedynie jako rezerwuar środków, pozbawionej ograniczeń i samoograniczeń egoistycznej i egocentrycznej ludzkiej aktywności. Rewaloryzowane są te wszystkie stanowiska, które podkreślają konieczność szacunku wobec przyrody, ochrony jej dóbr i zasobów oraz konieczności harmonijnego współżycia.

Podkreśla się, że idea harmonii pomiędzy społeczeństwem a przyrodą ma długą historię. Jak sądzi się obecnie, była przedmiotem 
uwagi w systemach religijnych organizujących życie ludzkich społeczności już u jego początków (Sadowski 2015). Kwestie te okazały się istotne również na gruncie filozofii. Osiemnasto i dziewiętnastowieczny zwrot ku naturze zaowocował dojrzałymi wizjami związku człowieka z naturą (Thoreau 2010). W dziewiętnastym wieku problematyka ta zakorzeniła się na gruncie nauki - analizą tych związków w wymiarze teoretycznym i problemowym zajęły się takie dyscypliny, jak: ekologia, socjobiologia czy sozologia.

Nieodległą historią, ostatnich kilku dziesięcioleci, legitymuje się ekofilozofia, której „...przedmiot zainteresowań skoncentrowany jest wytacznie na wieloaspektowych dociekaniach nad związkami człowieka ze środowiskiem przyrodniczym w świetle dokonujacych sie przemian cywilizacyjnych" (Tyburski 2011). Ekofilozofia, jako nowa dyscyplina odnosi się do świata przyrody w powiązaniu z rozwojem cywilizacyjnym spowodowanym wyraźną ingerencją człowieka, która prowadzi do kryzysu tego środowiska. Specyfika tej dyscypliny oparta jest na wskazaniu postrzegania miejsca człowieka w świecie przyrody i wzajemnych związków środowiska społecznego i przyrodniczego z nowej perspektywy. Bardziej szczegółową nauką, która wyłoniła się na gruncie ekofilozofii jest sozologia - nauka o czynnej ochronie środowiska naturalnego. Zajmuje się ona problemami ochrony środowiska, wskazując na przyczyny i następstwa niekorzystnych zmian w strukturze i funkcjonowaniu ekosystemów, wynikających z rozwoju działalności człowieka.

Na aksjologię zrównoważonego rozwoju zasadniczy wpływ ma jednak relacja, dokonująca się na gruncie nauki, w zakresie określenia kondycji globu. Epoka, w której obecnie żyjemy znajduje odzwierciedlenie w obecnej fazie rozwoju globu jako antropocen. Nic bowiem lepiej niż termin antropocen $^{2}$ nie ujmuje natury naszego

2 Antropocen - termin zaproponowany przez Paula Crutzena, dla określenia obecnej epoki geologicznej, w której człowiek staje się zasadniczą silą sprawczą w dziejach globu. czasu. Określenie obecnej epoki geologicznej, zdominowanej działalnością człowieka, nawiązuje do wpływu człowieka na funkcjonowanie procesów przyrodniczych zachodzących w skali Ziemi. Przejawem tego jest gwałtowna urbanizacja świata, szybkie wyczerpywanie przez człowieka paliw kopalnych, gromadzonych w naturze przez setki milionów lat, zwiększona wskutek ich konsumpcji emisja gazów cieplarnianych oraz zanieczyszczenie środowiska. Postulatora antropocenu poparli geologowie: Jan Zalasiewicz i Mark Williams z Uniwersytetu w Leicester w Wielkiej Brytanii oraz Daniel Richter z Uniwersytetu Duke'a w USA. Uczeni ci wezwali międzynarodową Komisję Stratygraficzną, by ogłosiła, że żyjemy w epoce antropocenu. Grożą nam zmiany klimatyczne, temperatura Ziemi wzrosła o $1^{\circ} \mathrm{C}$ w ciągu ostatnich 100 lat. To dopiero początek globalnego ocieplenia, a już świat zmienia się na naszych oczach. W ciągu ostatnich 20-tu lat obserwowany jest szczególnie szybki wzrost temperatury na Ziemi. Od momentu rozpoczęcia regularnych pomiarów w 1850 roku aż 11 spośród ostatnich 12 to najcieplejsze lata w historii pomiarów.

Gdy więc spojrzymy na treści kryjące się pod nazwą antropocenu, zauważyć musimy, że w warstwie opisowej antropocen wyraża na gruncie nauki, obiektywizację opisu zagrożenia dla dalszego rozwoju ludzkości. To samo pojęcie antropocen jako punkt wyjścia refleksji aksjologicznej stanowi przesłankę postulatu zrównoważonego rozwoju.

\section{Aksjologia zrównoważonego rozwoju a wartości uznawane przez polskie społeczeństwo w badaniach}

W artykule niniejszym zasadniczym problemem jest konfrontacja świadomości Polaków, którzy wypowiadali się na temat dziesięciu najważniejszych wartości w ich życiu z aksjologią rozwoju trwałego i zrównoważonego jako pożądanym horyzontem wartości. Relacja między świadomością empiryczną i pożądaną stanowi punkt wyjścia dla propozycji dotyczącej edukacji, wspomagającej likwidowanie tego rozdźwięku. Punktem 
ogniskującym związek edukacji globalnej z empiryczną świadomością edukowanych jest holistyczna edukacja dla zrównoważonego rozwoju. W artykule zwraca się uwagę na znaczenie kształtowania systemu wartości podczas edukacji od najmłodszych lat życia dziecka. Uświadomienie, że człowiek jest częścią przyrody, która stanowi podstawową wartość dla jego egzystencji jest ważnym zadaniem zarówno rodziców jak i nauczycieli.

W artkule wykorzystano wyniki badania przeprowadzonego przez Centrum Edukacji Obywatelskiej (CEO) zamieszczone na forum internetowym, w którym ludzie wymieniali wartości najważniejsze w ich życiu. Wyniki te były również wykorzystywane w projekcie ogólnopolskim na platformie: Szkoła z Klasą 2.o. Z losowo wybranych odpowiedzi Internautów zapytanych o 10 najważniejszych wartości w ich życiu wyodrębniono trzy grupy odpowiedzi, które oznaczono jako: X, Y, Z. Internauci jako 10 podstawowych wartości najczęściej wymieniali (web-o1):

Najczęściej podawane odpowiedzi grupy X:

1. Bóg - chyba nie muszę tłumaczyć dlaczego

2. Zdrowie - życie bez zdrowia nie jest w pełni szczęśliwym życiem

3. Miłość - miłość do bliźniego. Życie bez miłości to tak jak komputer bez internetu.

4. Rodzina - ktoś musi nas wspierać duchowo

5. Honor - każdy powinien mieć swój honor i odwagę.

6. Pieniądze - tylko bogaci mogą powiedzieć, że pieniądze szczęścia nie dają, owszem pieniądze są potrzebne.

7. Rozsądek - tak żeby nie zginąć wśród ludzi, by kierować się nim i używać go jak najczęściej.

8. Szczęście - potrzebne jest szczęście, bo bez szczęścia człowiek odnosił by mało sukcesów.

9. Ojczyzna i patriotyzm - mężne stawanie w obronie swojego kraju.

10. Talent - dar talentu, żeby mieć zamiłowania i umiejętność.
Grupa Y wskazuje na nieco inną kolejność wartości:

1. Miłość

2. Rodzina

3. Przyjaźń

4. Wiara

5. Spokój

6. Zdrowie

7. Wolność

8. Mądrość

9. Szczerość

10. Prawda.

Grupa Z wskazuje:

1. Sens - bez sensu nie ma sensu

2. Jakieś więzi z innymi ludźmi

3. Talent

4. Pieniądze

5. Inteligencja

6. Spokój

7. Zdrowie

8. Seks

9. Wolność

10. Sprawiedliwość".

Środowisko, przyroda nie została wymieniona jako wartość w żadnej z grup odpowiedzi. Prawdopodobnie została uznana za coś tak oczywistego jak powietrze, które zdaje się być niewyczerpywalne, a więc nie zasługujące by je cenić na tyle, by o nim pamiętać. Podobnie oczywista i nie zasługująca na umieszczenie w obszarze rzeczy cennych wydaje się przyszłość człowieka, jako gatunku gospodarującego na Ziemi. Ironizując, oczywiste się wydaje iż: Byliśmy, jesteśmy, będziemy. Niewspółmierność tradycyjnych hierarchii wartości wobec wyzwań współczesności, czyni edukację rozbudzającą świadomość istnienia problemów najważniejszym wyzwaniem. Pisał o tym cytowany już Bogdan Suchodolski. Pytaniem pozostaje jedynie droga, na jakiej można to osiągnąć.

\section{Edukacja na rzecz zrównoważonego rozwoju (EZR)}

Wydaje się, że relacje dotyczące człowieka i przyrody podejmuje holistyczna edukacja dla zrównoważonego rozwoju wskazując na to, że: „Spędzanie dużej ilości czasu na tonie przyrody przynosi wiele korzyści dla 
zdrowia fizycznego i psychicznego, dla funkcji poznawczych i kreatywności. Jest wiele badań, które wykazuja, że kontakt z przyroda może redukować symptomy ADHD, ttumić depresję, niepokój, zapobiegać otytości i krótkowzroczności, wzmacniać układ odpornościowy oraz więzi społeczne". (Louv 2016). Autor, w swojej książce zatytułowanej „Ostatnie dziecko lasu”, przebywanie w naturze nazywa witaminą „N”.

Dla rozwijania rozumienia wartości kształtowanych poprzez edukację przyrodniczą, należy uwzględnić zrównoważony rozwój definiowany jako: postęp, w którym następuje zaspokajanie aspiracji rozwojowych obecnego pokolenia, przy zachowaniu środowiska przyrodniczego w stanie umożliwiającym realizację tych samych dążeń następnym pokoleniom. Komponentami ZR są: środowisko, społeczeństwo i ekonomia. O edukacji dla zrównoważonego rozwoju możemy mówić wtedy, gdy rozumiana jest definicja ZR oraz kiedy uwzględnia się w edukacji przynajmniej dwa $\mathrm{z}$ trzech przedstawionych komponentów.

Przyroda jest wielką wartością dla człowieka, jest naturalnym środowiskiem życia, o które należy dbać i chronić przed dewastacją i degradacją. Zanieczyszczenia środowiska spowodowane działalnością człowieka, powodując coraz gorszy komfort życia, zwracają się przeciw niemu. Brak aktywności fizycznej często jest skutkiem braku kontaktu z przyrodą, następstwem tego mogą być choroby cywilizacyjne. Przykładem jest otyłość, będąca skutkiem siedzącego trybu życia. Choroby cywilizacyjne, wiążą się z wieloma powikłaniami, których skutki odczuwamy przez całe życie. Lekarze coraz częściej diagnozują tzw. „zespół cieśni nadgarstka", który rozwija się u osób używających zbyt często myszy komputerowej. Choroba ta w odróżnieniu od złamań czy zwichnięć kości może trwać przez całe życie.

Pedagodzy coraz częściej diagnozują wśród dzieci niepokojące objawy związane z brakiem kontaktu z przyrodą. W Polsce jest to wciąż niedoceniane znaczenie jakie ma kontakt $\mathrm{z}$ naturą. Jest to zapewne związane jest z wkroczeniem technologii informacyjnych do codziennego życia i fascynacja, która odwraca uwagę dzieci od naturalnego środowiska. Dzieci pozbawione terapeutycznych właściwości przyrody cierpią coraz bardziej z powodu stresu, zmęczenia i obniżonej koncentracji uwagi, co objawia się znudzeniem, impulsywnością, irytacją. Wirtualny świat, którym jesteśmy otoczeni, dostarcza naszym dzieciom nadmiar bodźców. Z drugiej strony ogranicza możliwość poznawania świata innymi zmysłami niż wzrok i słuch. Konsekwencje tego zjawiska określa się jako zespół deficytu natury (Louv 2016). Korzyści wynikające z doświadczeń kontaktu z przyrodą okazują się bardzo cenne w rozwoju człowieka. Są to między innymi:

- $\quad$ większe skupienie w przypadku dzieci nadpobudliwych,

- większa wrażliwość i kreatywność,

- spadek poziomu stresu,

- równowaga w postrzeganiu świata wieloma zmysłami,

- $\quad$ spostrzegawczość wynikająca z umiejętności obserwacji.

Przy założeniu, że wartości są konstruktem motywacyjnym i odnoszą się do pożądanych celów kształcenia, podczas pracy dydaktycznej warto formułować konkretne wartości, jakie daje nam kontakt z przyrodą. Nauczyciel powinien pamiętać, że rozwijanie wartości jest konsekwencją doświadczeń ucznia (Schwartz 2005:58). W praktyce kształtowania wartości można odwołać się do zajęć terenowych, w środowisku przyrodniczym. Podbudowę teoretyczną mogą na przykład stanowić, nawiązujące do edukacji zrównoważonego rozwoju przedstawione w Raporcie Jacquesa Delorsa, „Cztery Filary Edukacji” w kształceniu się przez całe życie (Delors 1998).

I. Uczyć się aby wiedzieć - wiedza staje się wartością, jeśli pobudza do poszukiwania różnego rodzaju rozwiązań, stanowi odpowiedzi na nurtujące go pytania, służy poprawie poziomu kompetencji człowieka. Taką wiedzę możemy dziecko zdobywa ucząc się 


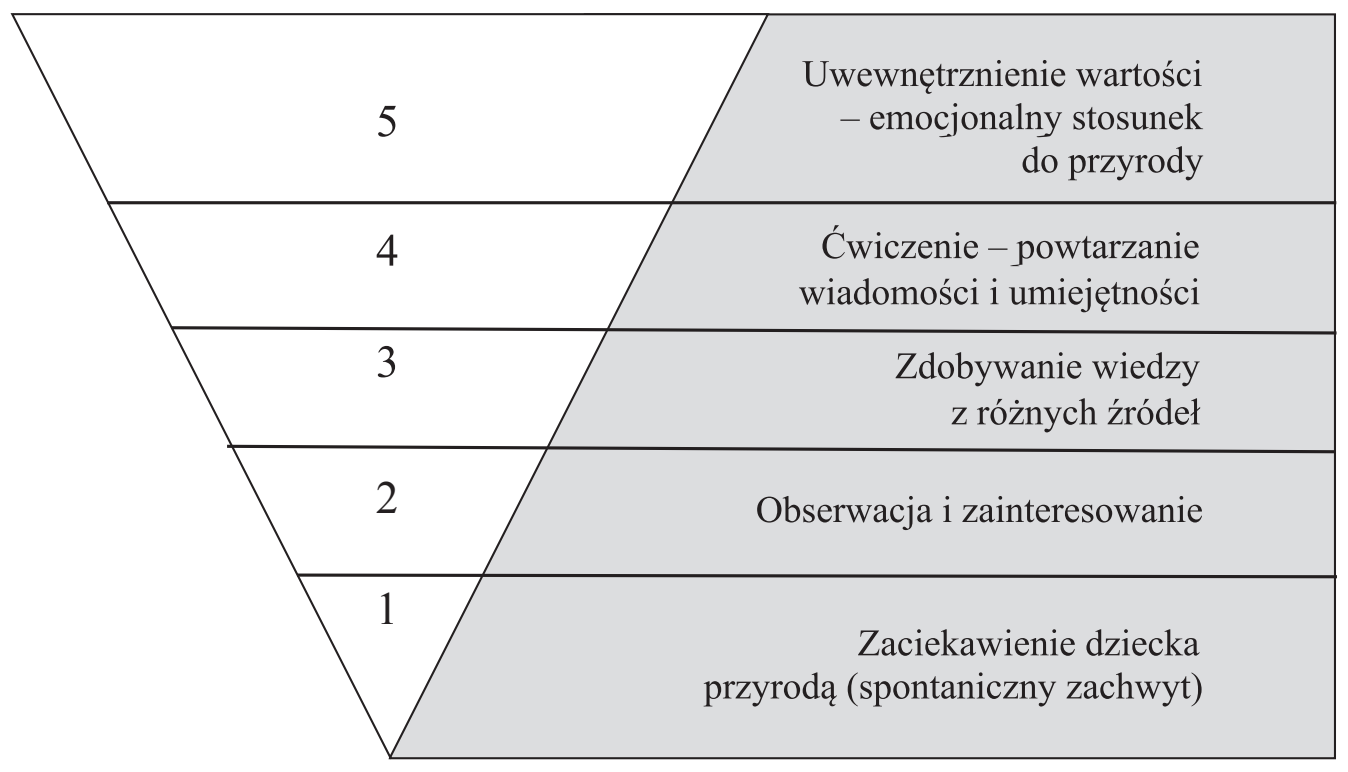

Rys. 1. Odwrócony model uczenia się o przyrodzie, w przyrodzie, dla przyrody

(Źródło: Tuszyńska 2016:120)

od przyrody poprzez obserwację zjawisk przyrodniczych i różnorodności roślin i zwierząt i ich cech morfologicznych i fizjologicznych itp.

II. Uczyć się aby działać - Ten filar edukacji dotyczy wartości praktycznych jakie są niezbędne do życia człowieka. Odnosząc się do przyrody można wskazać na racjonalne wykorzystywanie jej zasobów jako źródło pokarmu, substancji do produkcji leków itp. I choćby z tego powodu konieczności ochrony środowiska dla zachowania zdrowia człowieka.

III. Uczyć się aby żyć wspólnie - Uczenie się w środowisku przyrodniczym sprzyja umacnianiu przyjaźni, rozwojowi umiejętności pracy w grupie, opanowaniu sztuki dyskutowania i kreatywności zarówno nauczyciela, jak i uczniów.

IV. Uczyć się aby być - Odnosi się do humanizmu, prawa dziecka do bycia w przyrodzie, do refleksji, odbierania bodźców estetycznych itp.

Przedstawione elementy opisane jako „filary edukacji przez całe życie" powinny stać się inspiracją dla nauczycieli prowadzących edukację przyrodniczą i zrozumienia, holistycznego wymiaru edukacji dla zrównoważonego rozwoju.

W ujęciu dydaktycznym sugerujemy nauczycielom podjęcie próby dochodzenia do kształtowania wartości poprzez zastosowanie „Odwróconego modelu uczenia się..." , który charakteryzuje spontaniczne uczenie się przez obserwację, odkrywanie, zdziwienie, zainteresowanie... co wpływa na podnoszenie poziomu świadomości ekologicznej ucznia i podnoszenie kompetencji nauczyciela.

\section{Zakończenie}

Kiedy dziecko obserwując przyrodę dziwi się, jest zaskoczone widokiem jakiegoś organizmu czy zjawiska - następuje zaciekawienie przyrodą i spontaniczny zachwyt... pojawia się chęć dalszej obserwacji i zainteresowanie. Dzieci zaczynają dyskutować, poszukują informacji z różnych źródeł, pytają siebie nawzajem, pytają nauczyciela, w domu opowiadają rodzicom o zdarzeniu, szukają informacji w Internecie, w książkach, dyskutują w szkole następnego dnia. Często starają się powtórzyć podobną sytuację, np. idą do miejsca, gdzie zaobserwowały dane 
zjawisko (zwierzę, roślinę). Wytwarza się emocjonalny stosunek do przyrody. Miejsce w naturze, zwierzę czy roślina staje się dla ucznia wartością. Podnosi się poziom świadomości ekologicznej, kształtuje się postawa wskazująca, że przyrodę trzeba chronić. Warto wyposażyć uczniów w narzędzia, które mogą wykorzystać w doświadczaniu przyrody (np. lupy, łopatki, sprzęt fotograficzny, klucze do rozpoznawania roślin i zwierząt itp.). Pozwólmy dzieciom na swobodne zachowanie się podczas zajęć w terenie a kontakt emocjonalny uwewnętrzni się jako wartość i szacunek dla przyrody.

Mówiąc o edukacji dla rozwoju zrównoważonego, podejmujemy problem złożony i niezwykle trudny w operacjonalizacji celów działań edukacyjnych. Wyzwanie, które się tutaj pojawia ma charakter całościowy i wszechogarniający. Nadanie egzystencji człowieka na Ziemi zrównoważonego i trwałego charakteru wydaje się wyzwaniem przekraczającym możliwości współczesnej edukacji.

Ów gąszcz problemów i wyzwań okazuje się jednak możliwy do pokonania metodą małych kroków - edukacji rozpoczynanej odpowiednio wcześnie, by człowiek jako dziecko poczuł z przyrodą bezpośrednią więź określającą jego przyszłe działania i wyobrażenia.

Te małe kroki rozpoczynające się od tego, że dziecko przestaje bać się ubrudzenia czy umorusania w kontakcie z przyrodą, że nie boi się położyć na ziemi, czy przyklęknąć rozpoczynają drogę ku świadomości wartości świata, który nas otacza i który okazuje się od nas coraz bardziej zależny.

Małe kroki nie kończą się w szkole. Jest rzeczą znamienną, że intelektualiści skupieni w Klubie Rzymskim po okresie stawiania wielkich fundamentalnych pytań doszli do strategii małych kroków otwierających nową fazę w działaniach Klubu. Ogłoszony w końcu lat dziewięćdziesiątych Raport zatytułowany Mnożnik Cztery. Podwojony dobrobyt -dwukrotnie mniejsze zużycie zasobów naturalnych. Nowy raport dla Klubu Rzymskiego (von Weizsäcker, 1999) prezentuje korzyści wynikające z codziennej aktywności nastawionej na ochronę przyrody - sortowanie odpadów, korzystanie z energii odnawialnej, wykorzystywanie energooszczędnych rozwiązań technicznych. Podjęcie tych idei w Niemczech, gdzie powstał wzmiankowany raport, stało się przesłanką praktycznej przebudowy świadomości społecznej, czyniąc z Nieniec kraj przodujący na drodze rozwoju zrównoważonego. Droga małych kroków jest chyba również drogą edukacji na rzecz zrównoważonego rozwoju w polskim społeczeństwie.

\section{Literatura}

Birnbacher D., 1999, Odpowiedzialność za przyszłe pokolenia, tłum. B. Andrzejewski, P. Jackowski, Oficyna Naukowa, Warszawa.

Botkin J., Elmandjra M., Malitza M. 1982, Uczyć się bez granic. Jak zewrzeć „lukę ludzką”? Raport dla Klubu Rzymskiego, tłum. M. Kukliński, PWN, Warszawa.

Blundtland G.H., 1991, Wstęp (w:) Nasza wspólna przyszłość. Raport Światowej Komisji do spraw Środowiska i Rozwoju, tłum. U. Grzelońska, E. Kolanowska, PWE, Warszawa.

Ciążela H., 2006, Problemy $i$ dylematy etyki odpowiedzialności globalnej, Wyd. APS, Warszawa.

"Człowiek i jego środowisko". Raport Sekretarza Generalnego ONZ U Thanta $z$ dn. 26. V.1969 r. (w:) Dajcie szansę Ziemi, (1971), wybór. J. Zieliński, brak tłumacza , KiW, Warszawa .

Delors J., 1998, „Edukacja: jest w niej ukryty skarb”, Raport dla UNESCO: Międzynarodowej Komisji do spraw Edukacji dla XXI wieku http://www. unesco.org/delors/ (fragment pochodzi z jedynej dostępnej polskojęzycznej wersji Raportu, wydanej przez Stowarzyszenie Oświatowców Polskich)

Domeracki, P., 2001, Zrównoważony rozwój jako nowa etyka przyszłości, Edukacja i Kultura, nr 4, (78), 7-20.

Hull, Z., 2005, Filozofie zrównoważonego rozwoju, w: A. Papuziński (red.), Zrównoważony rozwój. Od utopii do praw człowieka, Bydgoszcz, 57-60. Jonas, H., 2003, Idea Boga po Auschwitz, tł. G. Sowiński, Wyd. Znak, Kraków.

Jonas, H., 1996, Zasada odpowiedzialności. Etyka dla cywilizacji technologicznej, tłum. M. Klimowicz, Wyd. Platan, Kraków. 
Kowalczyk S., 1986, Filozoficzne koncepcje wartości, Collectanea Theologica, 56 f. I, 37.

Louv R., 2010, O zachwycie natura $i$ konstruktywnej nudzie. Z Richardem Louvem rozmawia Jan van Boeckel , Miesięcznik „Dzikie Życie” 6/192 czerwiec 2010.

Meadows D. H., , Meadows D., Randers J, Behrens III W.W., 1973, Granice wzrostu, tłum. W. i S. Rączkowscy, PWE Warszawa.

Nasza wspólna przyszłość. Raport Światowej Komisji do spraw Środowiska i Rozwoju, 1991, tłum. U. Grzelońska, E. Kolanowska, PWE, Warszawa.

Papuziński, A., 2005, Wstęp [w:] Zrównoważony rozwój. Od utopii do praw człowieka, Bydgoszcz, 10.

Picht G., 1981, Odwaga utopii, PIW Warszawa.

Picht G., 1980-1981, Hier und Jetzt. Philosophieren nach Auschwitz und Hiroshima, Verlag KlettCotta, t.1 -Stuttgart 1980; t.2- Stuttgart 1981.

Sadowski R.F., 2015, Filozoficzny spór o rolę chrześcijaństwa w kwestii ekologicznej Towarzystwo Naukowe Franciszka Salezego, Warszawa.

Suchodolski B., 1947, Wychowanie dla przyszłości, Książnica Polska, Warszawa.

Schwartz, S. H. 2005, Robustness and fruitfulness of a theory of universals in individual human values. W: A. Tamayo, J. Porto (red.), Valores e comportamentos nas organizações. Petrópolis, Brazil: Vozes 56-95.
Tatarkiewicz W., 1990, Historia filozofii, T. I, Warszawa, 104-120.

Thoreau D. H., 2010, Walden, tłum. H. Cieplińska, Rebis Poznań.

Tuszyńska, L., 2016, Przyroda jako wartość wczesnej edukacji dziecka, [w:] L. Tuszyńska (red.) Koncepcja zrównoważonego rozwoju w kształceniu nauczycieli klas poczatkowych, Warszawa: Wyd. APS.

Tyburski W., 2011, Człowiek - środowisko przyrodnicze w'świetle wybranych stanowisk filozoficznych i ekofilozoficznych, Paedagogia Christiana 2/28, 1-2.

Tyburski, W., 2007, Filozoficzne i aksjologiczne zatożenia edukacji dla zrównoważonego rozwoju, [w:] B. Poskrobko, (red.), Obszary badań nad trwatym i zrównoważonym rozwojem, Białystok, 119.

von Weizsäcker E.U., Lovins A.B, Hunter Lovins L., 1999, Mnożnik Cztery. Podwojony dobrobyt_-dwukrotnie mniejsze zużycie zasobów naturalnych. Nowy raport dla Klubu Rzymskiego, tłum. z oryginału A. Lis, Polskie Towarzystwo Współpracy z Klubem Rzymskim, Wydawnictwo Rolewski, Toruń.

(web-01) Jakie może być 10 podstawowych wartości w życiu dla każdego człowieka, http://zapytaj. onet.pl/Category/002,018/2,10603526,Jakie_moze_ byc_10_podstawowych_wartosci_w_zyciu_dla_ kazdego_czlowieka.html, dostęp: 16.10.2016.

\section{Nature as a value in education for sustainable development}

\section{Summary}

The values related to sustainable development are rooted in fundamental threats which are connected with a human being. The imbalance of development of modern civilization entails a threat to the humanity. Concern for the environment which is not taking into account the aspirations and social strivings may become a source of conflicts and tensions that could destabilize the political situation. The article draws attention to the relationship of man with nature from an early age. The formation of values in relation to the surrounding nature and the nearest child's environment may contribute to the sustainable development.

\section{Keywords}

education, nature, values, sustainable development 